\title{
PENGEMBANGAN MEDIA PEMBELAJARAN BERBASIS LECTORA INSPIRE YANG DIINTEGRASIKAN DENGAN CAMTASIA STUDIO PADA MATA PELAJARAN GEOGRAFI MATERI SISTEM INFORMASI GEOGRAFIS
}

\author{
Yemima Otoluwa ${ }^{\mathrm{a}}$, Sunarty Eraku ${ }^{\mathrm{b}}$, Daud Yusuf ${ }^{\mathrm{c}}$ \\ ${ }^{a}$ Universitas Negeri Gorontalo, Jln Jendral Sudirman, Kota Gorontalo 96128, Indonesia
}

\begin{tabular}{|c|c|}
\hline INF & \\
\hline $\begin{array}{l}\text { Status artikel: } \\
\text { Diterima: } 07-12-2019 \\
\text { Disetujui: } 07-12-2019 \\
\text { Tersedia online: } 04-03-2020\end{array}$ & $\begin{array}{l}\text { evelopment of Lectora Inspire based Learning Media Integrated with Camtasia Studio } \\
\text { n Geography Subject of Information System Material. This research aims to develop } \\
\text { ectora Inspire based learning media on Geographic Information System material. } \\
\text { ectora Inspire is an application used to create learning media associated with }\end{array}$ \\
\hline $\begin{array}{l}\text { Kata kunci: } \\
\text { Lectora Inspire, Geographic Information } \\
\text { System, ADDIE, Camtasia Studio }\end{array}$ & $\begin{array}{l}\text { Geographic Information System material which is integrated with Camtasia Studio. It } \\
\text { applies a development research method with ADDIE model as an approach in } \\
\text { compiling the learning media, Moreover, the validation are conducted by material } \\
\text { expert, media expert, and subject expert. This learning media is tried out limited to high } \\
\text { school student of grade XII trough questionnaire. The collected data is research finding }\end{array}$ \\
\hline $\begin{array}{l}\text { Penulis korespondensi: } \\
\text { Yemima Otoluwa } \\
\text { Jurusan Ilmu dan Teknologi Kebumian, } \\
\text { Kota Gorontalo 96128, Indonesia } \\
\text { Email: yemimakoloay@ gmail.com } \\
\text { DOI: 10.34312/jgej.v1i1.4041 }\end{array}$ & $\begin{array}{l}\text { idation result from material expert reveals that the value of media validation } \\
\text { vided by validator I or material/content experts is } 83.75 \% \text { with valid category, } \\
\text { idator II or product design expert is } 88 \% \text { with very valid category, while validator III } \\
\text { subject expert or teacher of geography subject is } 98 \% \text { with very valid category. Thus, } \\
\text { average of students respond towards the learning media is } 88.8 \% \text {. }\end{array}$ \\
\hline
\end{tabular}

Copyright $\odot 2020$ JGEJ-UNG

All Rights Reserved.

\begin{abstract}
ABSTRAK:
Penelitian ini bertujuan untuk pengembangan media pembelajaran berbasis Lectora Inspire pada materi Sistem Informasi Geografis. Lectora Inspire merupakan aplikasi yang digunakan untuk membuat media pembelajaran yang berkaitan dengan materi Sistem Informasi Geografis yang diintegrasikan dengan Camtasia Studio. Penelitian ini menggunakan metode penelitian pengembangan dengan model ADDIE sebagai pendekatan dalam menyusun media pembelajaran tersebut. Validasi dilakukan oleh ahli materi, ahli media, dan ahli mata pelajaran. Media pembelajaran ini diujicobakan secara terbatas pada siswa SMA kelas XII dengan menggunakan angket. Data yang dikumpulkan berupa hasil penelitian mengenai kualitas media pembelajaran serta saran untuk revisi produk. Hasil validasi dari ahli materi menunjukan nilai validasi media yang diberikan oleh validator 1 atau ahli materi/isi dengan kategori valid adalah sebesar $83.75 \%$, validator II atau ahli desain produk memberikan penilaian sangat valid yaitu sebesar $88 \%$, sedangkan validator III atau ahli mata pelajaran dalam hal ini adalah guru pelajaran Geografi memberikan penilaian dengan kategori sangat valid yaitu sebesar 98\%. Rata-rata respon siswa terhadap media pembelajaran adalah $88.8 \%$.
\end{abstract}

This open access article is distributed under a Creative Commons Attribution-NonCommercial (CC-BY-NC) 4.0 International License

\section{Pendahuluan}

Pendidikan adalah sebuah proses yang berlangsung secara terus menerus (abadi) yang bersumber dari penyesuaian yang lebih tinggi untuk manusia dalam perkembangannya secara fisik maupun secara mental, yang sadar akan Tuhan, seperti termanifestasi dari alam sekitar emosional, intelektual dan kemanusiaan dari manusia. Peningkatan kualitas pendidikan dapat dilihat dari keberhasilan proses pembelajaran. Proses pembelajaran dikatakan berhasil apabila telah sesuai dengan standar proses yang sudah diatur dalam peraturan pemerintah. Kurikulum 2013 adalah kurikulum yang diterapkan oleh pemerintah pada saat ini yang merupakan pengembangan dari kurikulum sebelumnya yang lebih memperhatikan beberapa aspek, yaitu : sikap, pengetahuan dan keterampilan. Kurikulum 2013 tidak hanya menekankan pada aspek ilmiah saja namun pada nilai-nilai seni budaya dan moral. Hal ini penting karena tidak ada kinerja yang baik tanpa moral yang tinggi (Mulyasa, E. 2005). 
Dalam proses pembelajaran, pemerintah tidak lagi memiliki peran secara langsung untuk dapat mengembangkan kualitas pendidikan di Indonesia, akan tetapi lembaga sekolah dengan memenuhi fasilitas yang dapat menunjang proses pembelajaran, dalam hal ini guru, kelas, perangkat pembelajaran dan media pembelajaran yang akan meningkatkan potensi belajar siswa agar tidak mudah bosan dan lebih tertarik untuk mempelajari materi yang diajarkan oleh seorang guru. Penguasaan ilmu pengetahuan serta pemahaman yang cukup tentang media pendidikan haruslah dimiliki oleh seorang guru sebagai mediator dalam proses pembelajaran karena penggunaan media pendidikan menjadi alat komunikasi untuk dapat mengefektifkan proses belajar-mengajar ( Mulyasa, E. 2005 ).

Perkembangan ilmu pengetahuan dan teknologi semakin mendorong adanya inovasi dalam pemanfaatan teknologi dalam proses belajar. Kemajuan IPTEK berpengaruh terhadap penggunaan alat alat bantu mengajar disekolah dan lembaga pendidikan lainnya. Pembebelajaran berbasis teknologi informasi dan komunikasi telah mengubah pembelajaran berbasis media, diantaranya media komputer dan internet yang memunculkan E-learning ( Ulfatuzzahara, T. 2018 ).

Media merupakan segala alat yang dapat membuat siswa tertarik untuk belajar selama proses pembelajaran dan menyajikan pesan dalam materi kepada siswa ( Purba, S., \& Irwan RS Tambunan. 2017). Media dapat berupa penggunaan buku, vidio, film, animasi dan lain sebagainya. Penggunaan media pembelajaran harus dipilih dengan baik dan tepat agar dapat mendukung suasana dan kegiatan belajar mengajar. Media pembelajaran ini dapat membuat siswa untuk lebih aktif dan komunikasi dalam proses belajar, sehingga belajar lebih menyenangkan, tidak membosankan dan materi yang disampaikan oleh guru dapat dipahami oleh peserta didik. Pada tahapan orientasi pembelajaran hendaknya menggunakan media pembelajaran sehingga akan sangat membantu efektivitas pembelajaran dan penyampaian isi pelajaran.

Dalam kenyataannya beberapa guru SMAN 1 Telaga Biru masih menggunakan metode ceramah selama proses pembelajaran dan guru jarang sekali menggunakan media pembelajaran khususnya media pembelajaran berbasis ICT. Untuk media pembelajaran berbasis ICT ini, guru di SMAN 1 Telaga Biru lebih condong menggunakan media power point untuk menyampaikan materi namun media ini masih belum efektif untuk meningkatkan respon siswa dalam menguasai materi karena penyajian materi yang kaku dan terkesan membosankan. Media pembelajaran lain yang digunakan oleh guru di dalam kelas yaitu buku teks dan papan tulis, sehingga siswa kurang fokus terhadap materi yang di transfer oleh guru. Oleh karenanya, perlu adanya media yang mendukung seperti adanya tampilan gambar, vidio serta game edukasi untuk membantu peserta didik dalam mempelajari materi yang ada dalam buku teks dan siswa tidak merasa jenuh ketika belajar. Kebanyakan guru juga belum dapat membuat media pembelajaran interaktif sendiri untuk itu pengetahuan dan pemahaman yang cukup tendang media pembelajaran berbasis ICT haruslah dikuasai oleh seorang guru.

Berdasarkan permasalahan tersebut, pengembangan media pembelajaran yang dapat meningkatkan respon siswa selama di dalam kelas dan mendorong siswa lebih aktif dan komunikasi selama proses belajar sangat dibutuhkan. Sehingga media pembelajaran harus dikemas secara menarik dan menyenangkan agar dapat menarik perhatian para siswa untuk lebih semangat dalam mempelajari materi yang disajikan oleh guru. Media pembelajaran yang dapat diterapkan yaitu salah satunya media pembelajaran berbasis Lectora Inspire.

Merujuk dari penelitian Fauzani, A. (2017) Lectora Inspire adalah Authoring Tool untuk pengembangan konten elearning yang dikembangkan oleh trivantis Corporation. Lectora Inspire merupakan sebuah softwere yang dapat menyediakan berbagai konten interaktif yang bisa dijadikan media pembelajaran berbasis multimedia sehingga memudahkan selama proses belajar mengajar karena dalam softwere ini dilengkapi kemampuan untuk menggunakan audio, animasi, vidio, serta teknologi internet yang lebih canggih dibandingkan dengan media power point. Pada penelitian yang telah dilakukan media lectora inspire mempunyai potensi besar untuk meningkatkan motivasi belajar peserta didik dibandingkan pembelajaran konvensional ( Nursidik, H., \& Suri, I. R. A. 2018) . Selain itu penelitian oleh Purwendri, R. (2013) dengan menggunakan lectora inspire penelitian memperoleh hasil bahwa media berbasis lectora inspire dapat meningkatkan minat siswa dalam belajar sehingga memungkinkan siswa memahami pelajaran yang disajikan secara langsung.

\section{Metode}

\subsection{Lokasi dan Objek Penelitian}

Penelitian ini dilaksanakan di SMA Negeri 1 Telaga Biru Kabupaten Gorontalo. Sekolah ini telah ditetapkan sebagai salah satu sekolah ramah anak yang ada di Kabupaten Gorontalo. Sekolah ini berlokasi di Jl. Achmad Hiola, Desa Ulapato A, Kecamatan Telaga Biru, Kabupaten Gorontalo. Uji coba Penelitian Pengembangan Media Pembelajaran ini dilakukan di kelas XII IPS 2 yang memiliki siswa sebanyak 28 siswa yang terdiri dari 14 siswa laki-laki dan 14 siswi perempuan. Penelitian ini dilakukan selama 3 bulan yang 
dimulai dari bulan Agustus hingga Oktober selama semester ganjil tahun ajaran 2019/2020 pada materi Sistem Informasi Geografis.

Objek penelitian pengembangan media ini adalah aplikasi lectora inspire 17 yang diintegrasikan dengan Aplikasi Camtasia Studio 6 yang marupakan aplikasi bawaan dari lectora inspire.

\subsection{Prosedur Pengembangan}

Model pegembangan yang digunakan dalam penelitian ini adalah model ADDIE. Model ADDIE (Analysis, Design, Development, Implementation, dan Evaluation). Alasan penggunaan metode ini dikarenakan ADDIE memiliki prosedur kerja yang mengacu pada tahapan Research and Development $(R \& D)$.

\subsection{Metode Pengumpulan Data}

Metode yang digunakan dalam mengumpulkan penelitian adalah kuisioner (angket) dalam bentuk cheklist yang terdapat pertanyaan, wawancara digunakan untuk pengumpulan data ketika melakukan studi pendahuluan, observasi untuk mendapatkan gambaran nyata tentang lokasi dan proses belajar, dan dokumentasi.

Penelitian ini menggunakan instrumen penelitian yang terdiri dari empat instrumen yaitu instrumen validasi untuk ahli materi, instrumen validasi untuk ahli desain, instrumen validasi untuk ahli mata pelajaran, dan instrumen uji coba produk untuk siswa SMAN 1 Telaga Biru kelas XII IPS 2. Angket yang digunakan dalam instrumen tersebut dibuat secara berstruktur dengan bentuk pertanyaan terbuka untuk mendapatkan informasi kebutuhan untuk pengembangan media pembelajaran.

\subsection{Teknik Analisis Data}

Lembar validasi pemanfaatan media diisi oleh validator, yaitu ahli materi, ahli desain, dan ahli mata pelajaran. Penilaian terdiri dari 5 penilaian skor (Sukardi. 2009), yaitu :

$$
\begin{aligned}
& 5=\text { Sangat baik/Sangat layak } \\
& 4=\text { Baik/Layak } \\
& 3=\text { Cukup baik/Cukup layak } \\
& 2=\text { Tidak baik/Kurang layak } \\
& 1=\text { Tidak ada/Tidak layak }
\end{aligned}
$$

Untuk menentukan presentasi hasil data, maka digunakan rumus presentasi (Arikunto, S. 2019) sebagai berikut :

$$
P=\frac{\sum x}{\sum x^{1}} \times 100 \%
$$

Dimana :

\begin{tabular}{|c|c|c|}
\hline Persentase & Kualifikasi & $\begin{array}{c}\text { Kriteria } \\
\text { Kelayakan }\end{array}$ \\
\hline $\begin{array}{l}84 \%< \\
\text { skor } \leq \\
100 \%\end{array}$ & $\begin{array}{c}\text { Sangat } \\
\text { Valid }\end{array}$ & Tidak revisi \\
\hline $\begin{array}{c}68 \%< \\
\text { skor } \leq \\
84 \%\end{array}$ & Valid & Tidak revisi \\
\hline $\begin{array}{c}52 \%< \\
\text { skor } \leq 68 \\
\%\end{array}$ & $\begin{array}{l}\text { Cukup } \\
\text { Valid }\end{array}$ & Perlu revisi \\
\hline $\begin{array}{l}36 \%< \\
\text { skor } \leq\end{array}$ & $\begin{array}{l}\text { Kurang } \\
\text { Valid }\end{array}$ & Revisi \\
\hline
\end{tabular}

$$
\begin{aligned}
& \mathrm{P}=\text { Persentase } \\
& \sum x=\text { Jumlah total skor jawaban validator (nilai nyata) } \\
& \sum x^{1}=\text { Jumlah total skor jawaban tertinggi (nilai harapan) } \\
& 100=\text { Bilangan konstan }
\end{aligned}
$$

Hasil yang nantinya akan diperoleh dari perhitungan persentase, selanjutnya ditrntukan tingkat kelayakan produk hasil pengembangan. Pemberiian tingkat kelayakan produk menggunakan kualifikasi yang mempunyai kriteria berikut ini :

Tabel 1. Kualifikasi Tingkat Kelayakan 


\begin{tabular}{ccc}
\hline $52 \%$ & & \\
\hline $20 \%<$ & Sangat & \\
skor $\leq$ & Kurang & Revisi \\
$36 \%$ & Valid & \\
\hline
\end{tabular}

Data respon siswa yang diperoleh melalui angket dianalisis persentase dan kualifikasi untuk membuat kesimpulan apakah pengembangan media pembelajaran yang menggunakan aplikasi Lectore Inspire dapat menumbuhkan motivasi belajar bagi mahasiswa terkait dengan materi Sistem Informasi Geografis. Dalam menghitung persentase tiap respon siswa, maka digunakan rumus :

$$
P=\frac{\text { Jumlah respon siswa }}{\text { Jumlah siswa }} \times 100 \%
$$

Respon siswa dikatakan posistif jika $80 \%$ atau lebih siswa merespon dalam kategori positif untuk setiap aspek.

\section{Hasil dan Pembahasan}

\subsection{Hasil Penelitian}

\section{a. Tahap Analisis (Analysis)}

Selama proses mengajar guru berusaha untuk melakukan pembelajaran berdasarkan RPP yang memuat pembukaan, inti, dan penutup. Sebelum memulai kegiatan belajar, guru memberikan motivasi kepada siswa atau menanyakan materi sebelumnya yang telah dipelajari. Namun, ketika masuk ke bagian inti, pembelajaran Geografi ini masih dominan dengan metode ceramah dan terpusat pada buku paket geografi dan LKPD yang dimiliki. Terkadang juga guru hanya menugaskan siswa untuk merangkum materi dari buku paket sehingga siswa akan merasa mengantuk di kelas dan tidak konsentrasi. Selain itu, siswa kurang antusias mengikuti pembelajaran dikarenakan masih kurangnya kemampuan siswa dalam membaca. Ketika guru merasa siswa kurang fokus, guru hanya akan memberikan tugas latihan dan merangkum materi yang ada di buku paket geografi.

Hasil observasi yang dilakukan oleh peneliti di SMA Negeri 1 Telaga Biru, fasilitas pembelajaran atau ketersediaan media yang digunakan sudah cukup memadai. Buku geografi merupakan fasilitas yang disediakan sekolah untuk digunakan oleh guru selama proses pembelajaran. Pembelajaran dominan terhadap buku paket dan pengajaran yang masih terpusat pada guru. Penggunaan $L C D$ masih kurang karena memang terbatasnya fasilitas $L C D$ disekolah serta harus bergantian dengan guru yang lainnya. Beberapa masalah dalam pembelajaran ini juga didukung oleh Prasetyo, S. (2015) dalam jurnalnya yang berjudul Pengembangan Media Lectora Inspire dalam Pembelajaran Sains di Madrasah Ibtidaiyah yang menjelaskan bahwa beberapa masalah dalam pembelajaran tersebut perlu direnungkan dan diperbaiki agar sekolah berfungsi sebagai institusi yang memasok sumber daya manusia yang dapat menopang lajunya pembangunan khususnya dalam pembangunan ilmu pengetahuan dan teknologi bagi kesejahteraan manusia.

\section{b. Perencanaan (Design)}

Kerangka program yang digunakan berupa gambaran dari keseluruhan cakupan penyusunan media pembelajaran berbasis lectora inspire pada materi Sistem Informasi Geografis. Cakupan materi yang disajikan adalah materi tentang Pemanfaatan Peta, Penginderaan jauh dan Sistem Informasi Geografis (SIG). Materi ini termasuk pada materi semester genap di mata pelajaran geografi SMA kelas XII. Bagian evaluasi dalam media pembelajaran ini berisi soal-soal yang berhubungan dengan keseluruhan materi. Soal yang disajikan terdiri dari 5 butir soal dengan tipe multiple choice.

\section{c. Pengembangan (Development)}

Aplikasi media pembelajaran yang dibuat telah dirancang berdasarkan tahapan-tahapan yang ditetapkan, sehingga dapat menghasilkan produk berupa media pembelajaran berbasis multimedia interaktif yang berjudul Pemanfaatan Peta, Penginderaan jauh, dan Sistem Informasi Geografis. Tampilan pada media ini didesain seperti tampilan website yang terdiri dari sub-sub menu yang dapat dijalankan ketika memilih menu yang tersedia. Media ini dipublish dalam bentuk ekstension (.exe). pada saat aplikasi dijalankan maka akan muncul terlebih dahulu tampilan pembuka (splash screen) yang berisi ucapan selamat datang kepada pengguna. 


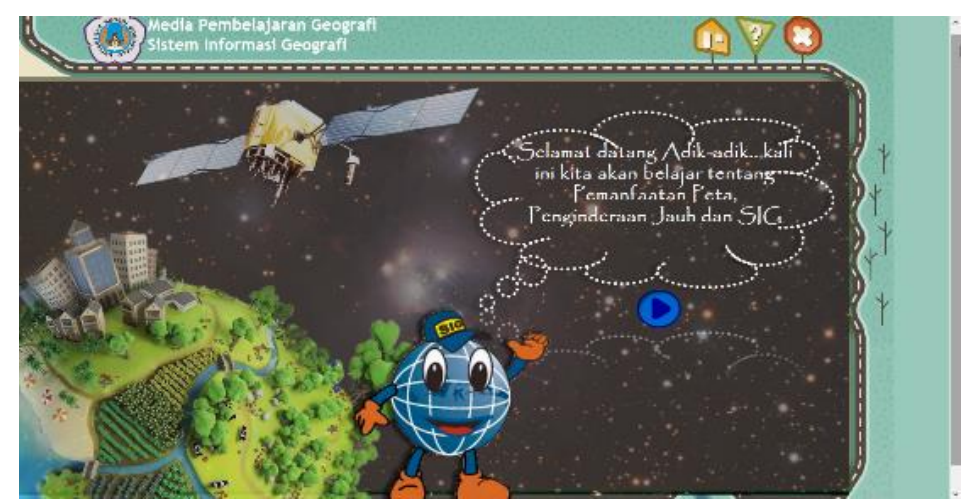

Gambar 1. Tampilan awal

Terdapat juga tombol bantuan yang membantu mengarahkan siswa dalam mengenal isi dari media pembelajaran ini serta fungsi dari setiap tombol yang digunakan dalam pengembangan produk ini. Materi yang di sajikan dalam media pembelajaran ini dilengkapi dengan gambar, text, vidio dan juga audio yang mendukung isi materi yang terkait.

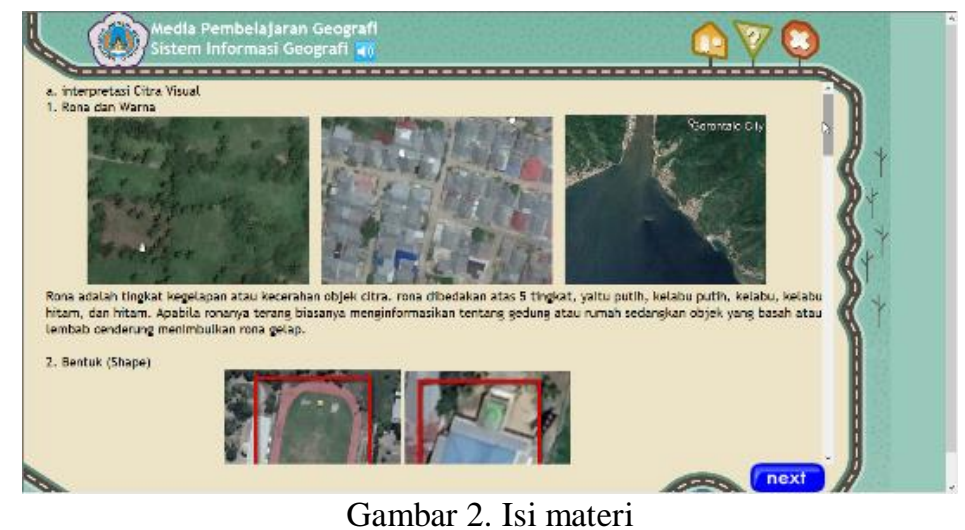

Materi yang disajikan dilengkapi dengan audio recording yang akan secara otomatis diputar setelah halaman dibuka. Setiap sub materinya juga banyak dilengkapi dengan contoh gambar seperti peta dan juga citra agar siswa mudah mengerti setiap penjelasan dari materi tersebut.

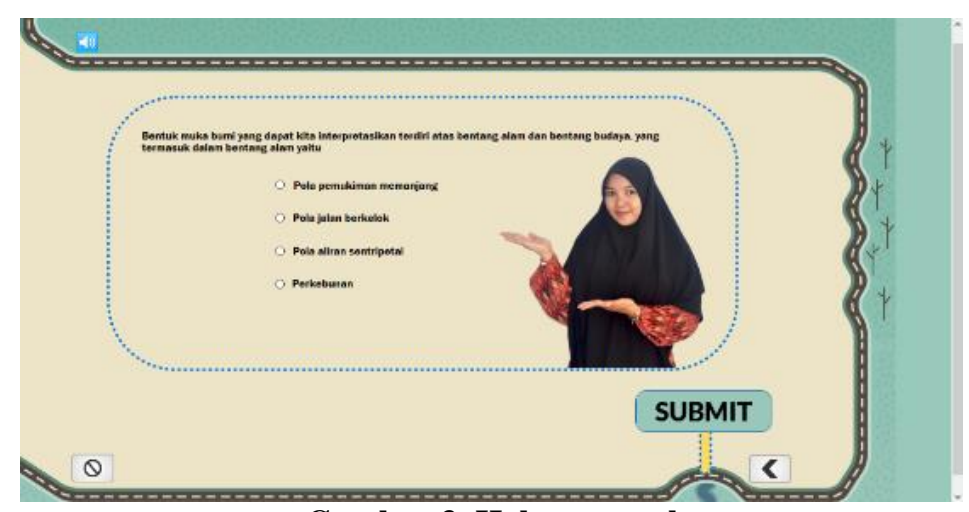

Gambar 3. Halaman soal

Dalam setiap latihan soal terdapat lima soal yang dapat dikerjakan oleh siswa dan diakhir jawaban siswa dapat melihat skor yang mereka peroleh dari setiap jawaban yang benar. Menu terakhir pada halaman menu utama adalah menu author yang berisi tentang profil pengembang. 


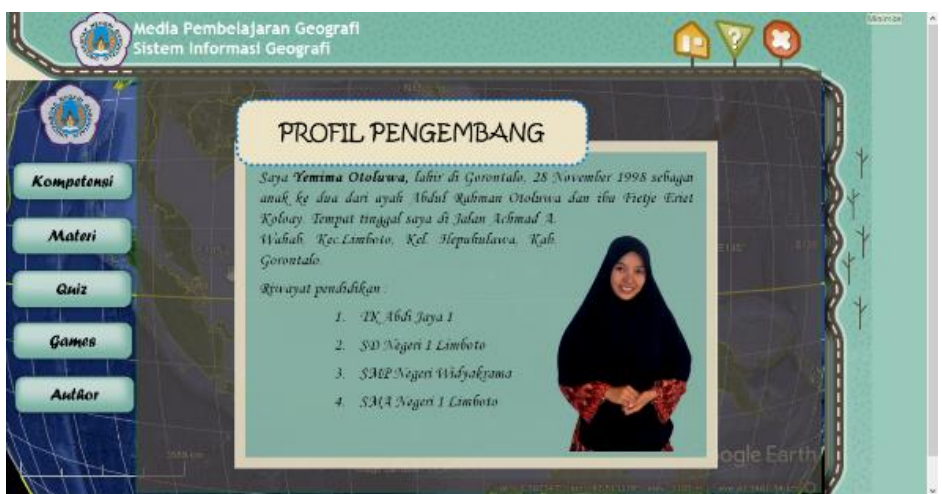

Gambar 4. Halaman author

Aplikasi media pembelajaran yang dibuat diperiksa kelayakannya sebagai media pemebelajaran oleh ahli materi, ahli media, dan ahli mata pelajaran. Hasil perhitungan dari ahli materi menunjukan persentase tingkat validasi sebesar $83.75 \%$. Berdasarkan hasil persentase tersebut maka dapat dilihat media pembelajaran ini berada pada kualifikasi valid dengan menyesuaikan hasil persentase pada tabel konversi skala kevalidan sehingga media pembelajaran berbasis lectora inspire tidak perlu direvisi lagi.

Penilaian dari ahli desain produk terhadap media pembelajaran yang dikembangkan, maka dapat dihitung persentase tingkat validasi media pembelajaran berbasis lectora inspire yang menghasilkan $88 \%$ yang berada pada kualifikasi sangat valid sehingga media pembelajaran ini tidak perlu dilakukan revisi. Hasil perhitungan persentase tingkat validasi dari ahli mata pelajaran menunjukan bahwa tingkat validasi sebesar $90 \%$ yang kemudian disesuaikan dengan tabel skala kevalidan, persentase tingkat pencapaian adalah $98 \%$ yang berada pada kualifikasi sangat valid sehingga media pembelajaran berbasis lectora inspire tidak perlu direvisi. Berdasarkan data yang diperoleh dari angket respon siswa, maka dapat diketahui bahwa nilai rata-rata dari kemenarikan media pembelajaran berbasis Lectora Inspire sebesar $88.8 \%$ dan berada pada kriteria yang sangat valid.

\section{d. Implementasi (Implementation)}

Media pembelajaran berbasis multimedia pada materi Sistem Informasi Geografis ini telah dikembangkan dengan melalui tahapan-tahapan validasi dan revisi sebagai persyaratan sah atau tidaknya sebuah karya ilmiah. Media pembelajaran berbasis Lectora inspire yang selesai dikembangkan telah dilakukan validasi kepada ahli materi, ahli desain media dan ahli pembelajaran.

Berdasarkan hasil validasi dari para ahli, menunjukan bahwa nilai validasi media yang diberikan oleh validator 1 atau ahli materi/isi dengan kategori valid adalah sebesar $83.75 \%$, validator II atau ahli desain produk memberikan penilaian sangat valid yaitu sebesar $88 \%$, sedangkan validator III atau ahli mata pelajaran dalam hal ini adalah guru pelajaran Geografi memberikan penilaian dengan kategori sangat valid yaitu sebesar $98 \%$.

Setelah media pembelajaran ini selesai direvisi kemudian dilakukan tahap uji coba penggunaan media kepada siswa kelas XII IPS 2 yang bertujuan untuk mengetahui respon dari para siswa terhadap media pembelajaran berbasis Lectora inspire yang dikembangakan. Uji coba dilakukan dengan memperkenalkan media kepada siswa yang dilakukan sendiri oleh peneliti. Setelah penggunaan media pembelajaran ini siswa dibagikan angket untuk diisi sebagai penilaian terhadap kelayakan media pembelajaran yang dikembangakan. Berdasarkan hasil dari uji coba terbatas yang dilakukan, rata-rata respon siswa terhadap media pembelajaran adalah $88.8 \%$

\section{e. Evaluasi (Evaluation)}

Media pembelajaran interkatif berbasis Lectora inspire yang telah melalui uji coba di dalam kelas lalu direvisi kembali apabila terdapat saran atau komentar dari siswa. Hasil akhir penelitian dan pengembangan ini adalah produk media pembelajaran interkatif berbasis lectora inspire untuk pembelajaran Geografi SMA kelas XII. Produk media pembelajaran interaktif berbasis lectora inspire dikemas dalam CD.

\subsection{Pembahasan}

Produk media pembelajaran yang dikembangkan peneliti berupa media pembelajaran berbasis Lectora Inspire telah melalui rangkaian tahapan untuk hasil yang maksimal, seperti tahap validasi oleh ahli media, ahli desain, dan ahli mata pelajaran, kemudian dilanjutkan dengan analisis respon siswa. 
Media pembelajaran berbasis Lectora Inspire memiliki 3 aspek yang sangat mendukung yaitu materi yang digunakan sesuai dengan buku acuan guru dan buku siswa kurikulum 2013 yang telah direvisi, perumusan indikator yang dimasukan dalam pengembangan media pembelajaran ini sesuai dengan analisis KI dan KD, materi dalam media pembelajaran ini dikemas dengan semenarik mungkin, dengan adanya musik siswa dapat lebih rileks ketika belajar, animasi yang dapat membuat siswa mudah menangkap arti dari animasi yang ditampilkan, vidio membantu siswa dalam memahami materi pembelajaran, gambar yang menarik dapat membuat siswa lebih tertarik dalam memahami gambar tersebut, dan juga disertai latihan soal yang dikemas ke dalam game yang menjadi karakteristik yang sangat kuat sebagai ketertarikan siswa terhadap media pembelajaran berbasis Lectora Inspire pada materi Sistem Informasi Geografis. Setelah melakukan uji coba kepada siswa, penyampaian materi yang dikemas dalam bentuk gambar, audio, vidio, animasi dan juga teks dalam media pembelajaran ini dapat diterima dengan baik oleh siswa kelas XII IPS 2 di SMAN 1 Telaga Biru. Hal ini sejalan dengan pendapat yang dikemukakan oleh Sukiman. (2012) tentang fungsi media pembelajaran yang dapat menarik dan mengarahkan perhatian peserta didik agar berkonsentrasi pada isi pelajaran, meningkatkan semangat peserta didik untuk belajar (atau membaca) teks yang tergambar, adanya gambar-gambar dapat memperlancar tujuan untuk memahami dan mengingat informasi atau pesan yang terkandung dalam gambar, dan dapat membantu peserta didik yang lemah dalam membaca untuk mengorganisirkan informasi dalam teks dan mengingatnya kembali.

Suasana belajar di dalam kelas juga tampak tenang karena semua siswa semangat dan terfokus untuk mempelajari serta memahami materi yang ada dalam media pembelajaran. Hal ini didukung dengan hasil respon siswa pada aspek yang ke sembilan yang menunjukan persentase $92.8 \%$ siswa semangat ketika menggunakan media pembelajaran berbasis Lectora Inspire ini.

Materi yang disajikan dalam media pembelajaran ini merupakan salah satu materi yang sulit dipahami oleh siswa karena kurangnya gambar dan membuat siswa berimajinasi sendiri ketika belajar materi SIG. Namun dengan adanya media pembelajaran berbasis Lectora Inspire ini dapat mengubah pola pikir siswa tentang betapa sulitnya mempelajari materi SIG karena dalam penyajiannya sudah disertakan dengan gambar peta yang berkaitan agar siswa dapat melihat langsung apa yang dijelaskan dari teks mengenai materi SIG. Hal ini didukung dengan hasil respon siswa terhadap media pembelajaran mengenai ketertarikan siswa untuk mempelajari materi SIG dengan menggunakan media pembelajaran berbasis Lectora Inspire yang menunjukan persentase $86.6 \%$ siswa tertarik. Hal ini sejalan dengan penelitian yang dilakukan oleh Ummi, A. (2018) dalam observasi awal yang dilakukannya di SMAN 10 Gowa yang menyatakan bahwa Biologi banyak mengandung konsep-konsep abstrak dan fenomena yang memerlukan observasi sehingga siswa harus melihat apa yang mereka pelajari. Dalam observasi tersebut para siswa menyatakan bahwa dalam pembelajaran Biologi, jika guru menggunakan media visual, baik pengajaran maupun pembelajaran Biologi dapat menjadi lebih efektif.

Berdasarkan analisis respon siswa di kelas XII IPS 2 yang berjumlah 28 siswa, menunjukan respon yang sangat baik terhadap media pembelajaran ini dengan persentase pencapaian rata-rata sebesar $88.8 \%$ yang artinya media pembelajaran berbasis Lectora Inspire ini sangat cocok untuk diterapkan kepada siswa selama proses pembelajaran berlangsung. Media pembelajaran ini juga dapat digunakan guru, karena dalam pengembangannya peneliti telah merancang media ini untuk dapat digunakan oleh siapa saja. Namun ada beberapa hal yang perlu diperhatikan ketika melakukan proses pembelajaran menggunakan media ini karena membutuhkan fasilitas penunjang seperti laptop, $L C D$, dan speaker.

\section{Kesimpulan}

Berdasarkan hasil penelitian yang didapatkan, menunjukan bahwa nilai validasi media yang diberikan oleh validator 1 atau ahli materi/isi dengan kategori valid adalah sebesar $83.75 \%$, validator II atau ahli desain produk memberikan penilaian sangat valid yaitu sebesar $88 \%$, sedangkan validator III atau ahli mata pelajaran dalam hal ini adalah guru pelajaran Geografi memberikan penilaian dengan kategori sangat valid yaitu sebesar 98\%. Rata-rata respon siswa terhadap media pembelajaran adalah $88.8 \%$ Sehingga dapat disimpulkan bahwa pengembangan media pembelajaran berbasis Lectora Inspire dapat digunakan dalam proses pembelajaran di kelas terkait dengan materi Sistem Informasi Geografis.

\section{Ucapan Terima Kasih}

Penulis mengucapkan banyak terimakasih kepada Kepala Sekolah SMAN 1 Telaga Biru yang telah memberikan izin melakukan uji coba penggunaan media pembelajaran kepada siswa. Ucapan terimakasih juga yang sebesar-besarnya kepada Bapak dan Ibu Dosen Pembimbing yang telah memberikan dukungan, 
arahan dan bimbingan sehingga hambatan dan kesulitan dapat peneliti selesaikan. Terimakasih juga untuk Elsa Putri Aryeningsih yang banyak memberikan bantuan tenaga dan waktu selama proses penelitian ini.

\section{Referensi}

Arikunto, S. (2019). Dasar-Dasar Evaluasi Pendidikan. In Dasar-dasar Evaluasi Pendidikan (Edisi 3).

Fauzani, A. (2017). Pengembangan Media Pembelajaran Berbasis Lectora Inspire Dalam Pembelajaran Tamrin Lughah Pada Siswa Kelas VIII MTS Ibnul Qoyyim Putra. UIN Sunan Kalijaga, 1-16.

Mulyasa, E. (2005). Menjadi guru profesional menciptakan pembelajaran kreatif dan menyenangkan. In Bandung: Remaja Rosdakarya.

Nursidik, H., \& Suri, I. R. A. (2018). Media Pembelajaran Interaktif Berbantu Software Lectora inspire. Desimal: Jurnal Matematika, 1(2), 237. https://doi.org/10.24042/djm.v1i2.2583

Prasetyo, S. (2015). Pengembangan Media Lectora Inspire dalam Pembelajaran Sains di Madrasah Ibtidaiyah. Jurnal Pendidikan Islam, IV(2), 319-337. https://doi.org/10.14421/jpi.2015.42.319-337

Purba, S., \& Irwan RS Tambunan. (2017). Pengembangan Media Pembelajaran Berbasis Aplikasi Lectora Inspire untuk Mata Pelajaran dan Pengukuran Listrik Kelas X di SMK Swasta Imelda Medan. Jurnal Manajemen Pendidikan, 9(1), 24-34.

Purwendri, R. (2013). Penggunaan Media Pembelajaran Dengan Program Berbasis Lectora Untuk Meningkatkan Minat Dan Hasil Belajar IPA Konsep Gerak Tropisme Pada Siswa SMP Kelas VIII. Jurnal Ilmiah Guru "COPE, 02.

Sukardi. (2009). Metodologi penelitian pendidikan: kompetensi dan praktiknya. In PENDIDIKAN METODOLOGI PENELITIAN, Metodologi penelitian pendidikan: kompetensi dan praktiknya. https://doi.org/2009.

Sukiman. (2012). Pengembangan Media Pembelajaran. Yogyakarta: Pedagogia.

Ulfatuzzahara, T. (2018). Pengembangan media pembelajaran berbasis lectora inspire pada mata pelajaran ips untuk meningkatkan hasil belajar siswa kelas vii smpn 01 dau malang.

Ummi, A. (2018). Pengembangan Media Pembelajaran Biologi Semester Ii Kelas X Sma Berbasis Lectora Inspire. Jurnal Nalar Pendidikan, 6(1), 41. https://doi.org/10.26858/jnp.v6i1.6041. 